\title{
Stochastic and Momentum Analysis of Nepalese Stock Market
}

\author{
Rashesh Vaidya*
}

Received on 2 September 2018; Revised on 5 November 2018; Accepted on 9 December 2018

\begin{abstract}
The stochastic oscillator is one of the popular tools used by technical analysts. The tools are used mainly to find the overbought and oversold position in the stock market. The stochastic values are between 0-100 which helps to determine the market scenario. The two stochastic indicators are comprised of two lines namely; $\% \mathrm{~K}$ and $\% \mathrm{D}$. The investors using the short-term moving average follows $\% \mathrm{~K}$ and for long-term moving average for \%D. Though, both are used for buy signal or sell signal by the investors. The basic concept is if, the value of $\% K$ is seen above $\% D$, which reflects to sell position, which in context to Nepalese stock market, the scenario is seen during the month of June-July of every fiscal year. At the same time, momentum uses transaction signal or trade signal or the zero 'O' line to find the bearish or bullish trend of the market. The momentum of NEPSE index clearly pictures out the bullish and the bearish trend for a specific duration. If the momentum line touches the 'zero line', the NEPSE has changed its trend.
\end{abstract}

Keywords: D, \%K, momentum, NEPSE, stochastic oscillator

\section{INTRODUCTION}

Lane (1985) in his paper concluded that the most reliable indicator was \%D for "\% of Deviation." The basic premise of $\% \mathrm{D}$ is that momentum leads price. It makes top before price and it makes bottom before price. Momentum is a leading indicator. $\% \mathrm{D}$ is a momentum oscillator.

Lee and Swaminathan (2000) showed that past trading volume gives a vital link between "momentum" and "value" strategies. Mainly, they located that firms with high (low) beyond turnover ratios show off many glamour (value) characteristics, earn decrease (high) future returns, and have consistently more negative (positive) earnings surprises over the next eight quarters. Past trading volume also predicts both the magnitude and persistence of price momentum. Specifically, price momentum effects reverse over the next five years, and high (low) volume winners (losers) experience faster reversals. Collectively, their findings show that beyond quantity helps to reconcile intermediate-horizon "under reaction" and long-horizon "overreaction" consequences.

Tonks and Hon (2003) investigated the presence of peculiar returns through using trading strategies that make the most the predictability of short-run stock price movements. Primarily based on historical returns of the biggest set of individual securities within the United Kingdom stock market examined to this point, this paper identified profitable momentum trading techniques as investment gear over

\footnotetext{
* Mr. Vaidya is Lecturer in Siddhartha Vanasthali College of Management, Kathmandu.

E-mail: rashesh_vaidya@hotmail.com
} 
the duration 1955-96. Their outcomes display that returns on trading techniques cannot be accounted for with the aid of a simple adjustment for beta-risk. Despite the fact that they determined proof of length effect within the United Kingdom stock market, this phenomenon cannot explain the momentum earnings. But, the paper found that those profitable investment strategies had been best apparent within the sub-sample 1977-96, and have been now not present in the earlier 1955-76 period. The implication is that momentum isn't always a widespread feature of the United Kingdom stock market, but is best apparent over certain time intervals.

Despite all the fancy and exotic tools technical analysis employs, it just studies of demand and supply in a market of the instruments in an attempt to determine what direction, or trend, the market will continue in the future. In other words, technical analysis attempts to understand the emotions in the market by studying the market itself, as opposed to its components. If an investor understands the benefits and limitations of technical analysis, it can give a new set of tools or skills that will enable you to be a better trader or investor.

The Stochastic Oscillator is based on the observation that closing prices tend to close to the upper end of the recent price range in up trends and to the lower end in downtrends (Murphy, 1999).The stochastic oscillator is another popular tool used by future technicians developed by George C. Lane (1921-2004) in 1984 who is also considered as 'Father of Stochastic'. Though, Lane himself has given credit of developing the stochastic oscillator to C. Ralph Dystant (1902-1978) in his paper. As an oscillator, it provides over-brought and over-sold readings, signals divergences, and affords a mechanism to compare a shorter-term trend to a longer-term trend. The stochastic indicator compares the latest closing price (index) with the total range of price (index) action for a specified period. Stochastic values are between 0 and 100. A high-stochastic reading would mean the close in near the upper end of the entire range for the period. A low reading means that the close is near the low end of the period's range. The idea behind stochastic is that, as the market moves higher, closes tend to be near the highs of the range or, as the market moves lower, prices tend to cluster near the lows of the range (Nison, 1991).

Oscillators are mathematically derived techniques which offer a more objective means of analyzing the market. They are widely used and are the basis of many computerized trading systems. Oscillators include such technical tools as the relative strength index, stochastic, and momentum. It can be used as divergence indicators i.e. when the price (index) and the oscillator move in different directions. Oscillators can confirm the force behind a trend's move by measuring the market's momentum (Nison, 1991).

The stochastic indicator compares the latest closing price (index) with the total range of price (index) action for a specified period. Stochastic values are between 0 and 100 .

Momentum indicators are a class of tools that are used measuring trend momentum and to detect situations when a stock is overbought or oversold (Murphy, 1999). Momentum, also called price velocity developed by Robert A. Levy in 1967, is a measurement of the difference between the closing price today and the closing price a specified number of days ago. If we use a ten-day momentum we compare today's close to that of ten days ago. If today's close is higher, the momentum is a positive number on the momentum scale. If today's close is lower than that of ten days ago, the momentum is a minus figure (Nison, 1991).

An overbought stock is a stock whose price has increased drastically over a short period of time and is trading at an unnaturally high price compared to recent price activity. If a stock is trading at an unnaturally high price the theory suggests that the price may reverse, thereby generating a sell signal. 
Similarly, an oversold stock is a stock whose price has fallen drastically over a short period of time, a situation that may indicate that the price will reverse to the upside, thereby generating a buy signal. When a stock is overbought it is usually a result of unjustifiably high demand, which means that the stock is probably overvalued and economic theory tells us that the market will soon adjust and the stock will probably experience a pullback. An oversold stock, however, usually indicates that the stock is undervalued a (fear or panic selling typically result in an oversold stock) which may signal a good shortterm investment opportunity (Turner, 2007).

Momentum, also called price velocity, is a measurement of the difference between the closing price today and the closing price a specified number of days ago. It is also handy as an overbought/oversold indicator. For instance, when the momentum index is at a relatively large positive value the market may be overbought and vulnerable to a price pullback. Momentum usually hits its peak before prices. Based on this, a much-overbought momentum oscillator could be presaging a price peak. Momentum measures the velocity of a price move by comparing price changes. In theory, the velocity should increase as the trend underway. A flattening of momentum could be an early warning that a price move may be decelerating (Nison, 1991).

In finance, momentum is the empirically observed tendency for rising asset prices to rise further. For instance, it was shown that stocks with strong past performance continue to outperform stocks with poor past performance in the next period with an average excess return of about $1 \%$ per month (Jegadeesh \& Titman, 1993; Jegadeesh \& Titman, 1999).

\section{DATA AND METHODS}

The paper has adopted a descriptive research design. The paper can yield rich data that lead to important recommendations in practice. The paper collected a large volume of data for the detailed analysis with respect to the stochastic and momentum analysis of Nepalese stock market. The open access secondary data available at the official web of the secondary market of Nepal, Nepal Stock Exchange Limited, that is, http://www.nepalstock.com/wasvisited for acquiring data needed for the paper. The stochastic oscillator developed by George C. Lane (1984), who is also known as a father of stochastic has been used for stochastic analysis of the Nepalese stock market.

The stochastic indicator is comprised of two lines, the $\% \mathrm{~K}$ and the $\% \mathrm{D}$ lines. The $\% \mathrm{~K}$ line, called the raw stochastic or the fast $\% \mathrm{~K}$, is the most sensitive. The formula for the $\% \mathrm{~K}$ line is:

$$
\frac{(\text { Close })-(\text { Low of } N)}{(\text { High of } N)-(\text { Low of } N)} \times 100=\% \mathrm{~K}
$$

where, $\quad$ Close $=$ Current Close

Low of $\mathrm{N}=$ Low of the range during the period used

High of $\mathrm{N}=$ High of the range during the period used

The " 100 " in the equation converts the value into a percentage. Thus, if the close today is the same as the high for the period under observation, the fast $\% \mathrm{~K}$ would be 100 Percent.

Most technicians use the slow $\% \mathrm{~K}$ line instead of the choppy fast $\% \mathrm{~K}$ line. This slow $\% \mathrm{~K}$ is smoothened using a three-day moving average of the slow $\% \mathrm{~K}$ to get what is called the $\% \mathrm{D}$ line. Here, the paper has conducted the three-month moving average. 
Momentum, also called price velocity, is a measurement of the difference between the closing price today and the closing price a specified number of days ago. The evaluation technique for momentum is that, if the momentum crosses under the ' 0 ' line, it could be constructed as a bearish sign, above the ' 0 ' line as bullish. Here, in the paper, the momentum is calculated by using the difference between the closing index and the moving average for the earlier twelve months closing index of a specific fiscal year.

The compiled data from the official website of Nepal Stock Exchange Limited was rearranged at the Microsoft Excel Sheet. Then, the formulae developed and used for the calculation of stochastic oscillator and momentum were implied for the NEPSE Indices (Open, High, Low and Close) for the period of F/Y 2001-02 to F/Y 2017-18. The monthly NEPSE Indices during the above mentioned fiscal year period have been used in the paper.

\section{RESULTS AND DISCUSSION}

\subsection{Stochastic Indicators Analysis}

Under the stochastic indicators, $\% \mathrm{~K}$ and $\% \mathrm{D}$ of the NEPSE have been calculated and interpreted.

Result of $\% K$

If the close is the same as the high for the period under observation, the fast $\% \mathrm{~K}$ would be $100 \%$. And at the same time, if the close is the same as the low for the period under observation, the fast $\% \mathrm{~K}$ would be $0 \%$. The result in Table 1 shows that the close is the same as the high for the month of June-July, most of the time in the past 17 years of the period at NEPSE. Except for the F/Y 2002-03, the value of \%K is seen at the high point. The $\% \mathrm{~K}$ was seen at $0 \%$ i.e. the close is the same as the low for the period during the month of February-March for six years.

The value of $\% \mathrm{~K}$ is at $100 \%$ then it can be stated that the market is bullish or in up-trend and when the value of $\% \mathrm{~K}$ is nearer to $0 \%$ then it can be stated that the market is going toward bearish or downtrend. Again, the $\% \mathrm{~K}$ was seen at $0 \%$ i.e. the close is the same as the low for the period during the month of January-February of F/Y 2016-17 and 2017-18 respectively.

\section{Result of $\% D$}

Most technicians use the slow $\% \mathrm{~K}$ line instead of the choppy fast $\% \mathrm{~K}$ line. This slow $\% \mathrm{~K}$ is smoothened using a three-day moving average of the slow $\% \mathrm{~K}$ to get what is called the $\% \mathrm{D}$ line. Here, the paper has conducted the three-month moving average as the paper has taken the monthly closing index for analysis purpose (See Table 2).

As the value of $\% \mathrm{D}$ is the outcome of the three-month moving average of the $\% \mathrm{~K}$, it is influenced by the earlier value of the $\% \mathrm{~K}$. The value of $\% \mathrm{D}$ for the Feb-Mar 2001-02 is seen 0.00 because the threemonth $\% \mathrm{~K}$ values were also 0.00 (zero).

Transaction signals are usually made when the $\% \mathrm{~K}$ crosses through the $\% \mathrm{D}$. An easy way to remember the difference between the two is to think of the fast stochastic as a sports car and the slow stochastic as a limousine. Like a sports car, the fast stochastic is agile and changes direction very quickly in response to sudden changes. The slow stochastic takes a little more time to change direction. Mathematically, the two oscillators are nearly the same except that the slow stochastic $\% \mathrm{~K}$ is created by taking a three-period average of the fast stochastic $\% \mathrm{~K}$. Taking a three-period moving average of each $\% \mathrm{~K}$ will result in the line that is used for a signal line. Close inspection will reveal that the $\% \mathrm{~K}$ of the slow stochastic is the same as the $\% \mathrm{D}$ (Signal Line) on the fast stochastic. 
Table 1

Value of $\% K$

\begin{tabular}{|c|c|c|c|c|c|c|c|c|c|c|c|c|}
\hline $\mathrm{F} / \mathrm{Y}$ & $\begin{array}{l}\text { Jul- } \\
\text { Aug } \\
\end{array}$ & $\begin{array}{l}\text { Aug- } \\
\text { Sept }\end{array}$ & $\begin{array}{l}\text { Sept- } \\
\text { Oct } \\
\end{array}$ & $\begin{array}{l}\text { Oct- } \\
\text { Nov }\end{array}$ & $\begin{array}{l}\text { Nov- } \\
\text { Dec }\end{array}$ & $\begin{array}{c}\text { Dec- } \\
\text { Jan } \\
\end{array}$ & $\begin{array}{l}\text { Jan- } \\
\text { Feb } \\
\end{array}$ & $\begin{array}{l}\text { Feb- } \\
\text { Mar } \\
\end{array}$ & $\begin{array}{l}\text { Mar- } \\
\text { Apr }\end{array}$ & $\begin{array}{l}\text { Apr- } \\
\text { May }\end{array}$ & $\begin{array}{c}\text { May- } \\
\text { Jun }\end{array}$ & $\begin{array}{c}\text { Jun- } \\
\text { Jul } \\
\end{array}$ \\
\hline 2001-02 & 0.93 & 17.84 & 79.07 & 100.00 & 2.91 & 0.00 & 0.00 & 0.00 & 91.10 & 84.18 & 0.00 & 82.12 \\
\hline 2002-03 & 100.00 & 0.00 & 35.66 & 24.19 & 0.00 & 0.00 & 51.35 & 51.86 & 3.71 & 0.00 & 1.23 & 29.59 \\
\hline 2003-04 & 100.00 & 68.86 & 64.43 & 0.00 & 0.00 & 79.86 & 84.00 & 2.36 & 45.92 & 78.64 & 71.44 & 64.95 \\
\hline 2004-05 & 100.00 & 39.43 & 0.00 & 100.00 & 16.21 & 100.00 & 100.00 & 88.60 & 103.52 & 0.67 & 23.16 & 100.00 \\
\hline 2005-06 & 67.61 & 41.80 & 100.00 & 45.83 & 100.00 & 63.73 & 100.00 & 81.05 & 10.63 & 100.00 & 15.92 & 100.00 \\
\hline 2006-07 & 78.93 & 44.54 & 91.48 & 97.51 & 100.00 & 100.00 & 43.52 & 35.34 & 51.38 & 75.25 & 88.04 & 100.00 \\
\hline 2007-08 & 59.12 & 86.59 & 46.92 & 99.22 & 100.00 & 1.95 & 47.46 & 0.00 & 100.00 & 100.00 & 100.00 & 100.00 \\
\hline 2008-09 & 73.77 & 0.00 & 0.00 & 19.43 & 37.92 & 0.00 & 86.84 & 0.00 & 7.22 & 92.24 & 17.58 & 100.00 \\
\hline 2009-10 & 24.59 & 19.94 & 0.00 & 0.00 & 100.00 & 0.00 & 25.67 & 0.00 & 0.00 & 92.95 & 14.92 & 100.00 \\
\hline 2010-11 & 0.00 & 0.00 & 100.00 & 73.13 & 2.16 & 70.33 & 17.97 & 0.00 & 70.77 & 26.43 & 0.00 & 97.85 \\
\hline 2011-12 & 15.19 & 5.51 & 79.57 & 0.00 & 16.33 & 93.37 & 0.00 & 38.46 & 138.87 & 56.28 & 2.14 & 100.00 \\
\hline $2012-13$ & 30.42 & 100.00 & 95.79 & 96.64 & 78.14 & 64.58 & 28.99 & 65.58 & 32.58 & 21.89 & 0.00 & 100.00 \\
\hline 2013-14 & 70.69 & 97.87 & 100.00 & 100.00 & 100.00 & 62.86 & 85.72 & 5.00 & 100.00 & 0.00 & 100.00 & 90.54 \\
\hline 2014-15 & 20.31 & 32.10 & 74.34 & 0.00 & 100.00 & 100.00 & 84.96 & 40.62 & 38.73 & 0.00 & 74.48 & 100.00 \\
\hline 2015-16 & 100.00 & 78.61 & 0.00 & 22.79 & 98.23 & 100.00 & 99.94 & 0.00 & 100.00 & 97.32 & 100.00 & 94.12 \\
\hline 2016-17 & 20.21 & 84.89 & 81.91 & 5.17 & 26.41 & 58.42 & 0.00 & 87.92 & 96.50 & 56.98 & 3.24 & 85.62 \\
\hline 2017-18 & 58.18 & 27.18 & 90.92 & 25.48 & 74.43 & 34.18 & 0.00 & 6.05 & 86.44 & 36.64 & 14.50 & 58.89 \\
\hline
\end{tabular}

Table 2

Source: Appendix-A

Value of $\% D$

\begin{tabular}{|c|c|c|c|c|c|c|c|c|c|c|c|c|}
\hline $\begin{array}{c}\text { Month } \\
\text { F/Y }\end{array}$ & $\begin{array}{l}\text { Jul- } \\
\text { Aug }\end{array}$ & $\begin{array}{l}\text { Aug- } \\
\text { Sept }\end{array}$ & $\begin{array}{l}\text { Sept- } \\
\text { Oct }\end{array}$ & $\begin{array}{l}\text { Oct- } \\
\text { Nov }\end{array}$ & $\begin{array}{l}\text { Nov- } \\
\text { Dec }\end{array}$ & $\begin{array}{l}\text { Dec- } \\
\text { Jan }\end{array}$ & $\begin{array}{l}\text { Jan- } \\
\text { Feb }\end{array}$ & $\begin{array}{l}\text { Feb- } \\
\text { Mar }\end{array}$ & $\begin{array}{l}\text { Mar- } \\
\text { Apr }\end{array}$ & $\begin{array}{l}\text { Apr- } \\
\text { May }\end{array}$ & $\begin{array}{l}\text { May- } \\
\text { Jun }\end{array}$ & Jun-Jul \\
\hline 2001-02 & - & - & 32.62 & 65.64 & 60.66 & 34.30 & 0.97 & 0.00 & 30.37 & 58.43 & 58.43 & 55.43 \\
\hline 2002-03 & - & - & 45.22 & 19.95 & 19.95 & 8.06 & 17.12 & 34.40 & 35.64 & 18.52 & 1.65 & 10.27 \\
\hline 2003-04 & - & - & 77.76 & 44.43 & 21.48 & 26.62 & 54.62 & 55.41 & 44.09 & 42.31 & 65.33 & 71.68 \\
\hline 2004-05 & - & - & 46.48 & 46.48 & 38.74 & 72.07 & 72.07 & 96.20 & 97.37 & 64.26 & 42.45 & 41.28 \\
\hline 2005-06 & - & - & 69.80 & 62.54 & 81.94 & 69.85 & 87.91 & 81.59 & 63.90 & 63.90 & 42.18 & 71.97 \\
\hline 2006-07 & - & - & 71.65 & 77.84 & 96.33 & 99.17 & 81.17 & 59.62 & 43.41 & 53.99 & 71.56 & 87.76 \\
\hline 2007-08 & - & - & 64.21 & 77.58 & 82.05 & 67.06 & 49.80 & 16.47 & 49.15 & 66.67 & 100.00 & 100.00 \\
\hline 2008-09 & - & - & 24.59 & 6.48 & 19.12 & 19.12 & 41.59 & 28.95 & 31.35 & 33.15 & 39.01 & 69.94 \\
\hline 2009-10 & - & - & 14.84 & 6.65 & 33.33 & 33.33 & 41.89 & 8.56 & 8.56 & 30.98 & 35.96 & 69.29 \\
\hline 2010-11 & - & - & 33.33 & 57.71 & 58.43 & 48.54 & 30.15 & 29.43 & 39.58 & 32.40 & 32.40 & 41.43 \\
\hline 2011-12 & - & - & 33.33 & 28.36 & 31.96 & 36.56 & 36.56 & 43.94 & 59.44 & 78.20 & 66.10 & 52.81 \\
\hline $2012-13$ & - & - & 75.40 & 97.48 & 90.19 & 79.79 & 57.24 & 52.99 & 42.32 & 39.95 & 18.16 & 40.63 \\
\hline 2013-14 & - & - & 89.52 & 99.29 & 100.00 & 87.62 & 82.86 & 51.20 & 63.58 & 60.20 & 91.87 & 88.72 \\
\hline 2014-15 & - & - & 42.25 & 35.48 & 58.11 & 66.67 & 94.99 & 75.19 & 54.77 & 26.45 & 37.74 & 58.16 \\
\hline $2015-16$ & - & - & 59.54 & 33.80 & 40.34 & 40.34 & 73.67 & 99.39 & 66.65 & 65.77 & 99.11 & 97.14 \\
\hline 2016-17 & - & - & 62.34 & 57.33 & 37.83 & 30.00 & 28.27 & 48.78 & 61.47 & 80.47 & 52.24 & 48.63 \\
\hline 2017-18 & - & - & 58.76 & 47.86 & 63.61 & 44.69 & 36.20 & 13.41 & 30.83 & 43.04 & 45.56 & 36.68 \\
\hline $2017-18$ & - & - & 58.76 & 47.86 & 63.61 & 44.69 & 36.20 & 13.41 & 30.83 & 43.04 & 45.56 & 36.68 \\
\hline
\end{tabular}


The transaction signals were seen in the months of Feb-Mar 2001-02, May-Jun 2002-03, Dec-Jan 2006-07, May-Jun 2007-08, Jun-July 2007-08 and May-Jun of the F/Y 2015-16 at the Nepalese stock market in the past one and a half decade.

\subsection{Momentum Analysis}

Momentum, also called price velocity, is a measurement of the difference between the closing price of the current period and the closing price a specified number of days or months ago. Figure 1 shows the NEPSE Index velocity for the F/Y 2001-02 to F/Y 2017-18.

Table 3

\section{Momentum Value}

\begin{tabular}{|c|c|c|c|c|c|c|c|c|c|c|c|c|}
\hline $\begin{array}{c}\text { Month } \\
\text { F/Y }\end{array}$ & $\begin{array}{l}\text { July- } \\
\text { Aug }\end{array}$ & $\begin{array}{l}\text { Aug- } \\
\text { Sept }\end{array}$ & $\begin{array}{l}\text { Sept- } \\
\text { Oct }\end{array}$ & $\begin{array}{l}\text { Oct- } \\
\text { Nov }\end{array}$ & $\begin{array}{l}\text { Nov- } \\
\text { Dec }\end{array}$ & $\begin{array}{l}\text { Dec- } \\
\text { Jan }\end{array}$ & $\begin{array}{l}\text { Jan- } \\
\text { Feb }\end{array}$ & $\begin{array}{l}\text { Feb- } \\
\text { Mar }\end{array}$ & $\begin{array}{l}\text { Mar- } \\
\text { Apr }\end{array}$ & $\begin{array}{l}\text { Apr- } \\
\text { May }\end{array}$ & $\begin{array}{l}\text { May- } \\
\text { June }\end{array}$ & $\begin{array}{c}\text { June- } \\
\text { July }\end{array}$ \\
\hline 2001-02 & -70.19 & -90.19 & -78.84 & -64.06 & -81.68 & -109.54 & -124.67 & -158.50 & -128.72 & -96.74 & -99.39 & -83.30 \\
\hline $2002-03$ & -71.18 & -62.70 & -54.62 & -44.39 & -42.83 & -48.86 & -30.35 & -27.07 & -19.30 & -23.05 & -19.17 & -17.19 \\
\hline 2003-04 & -10.31 & -7.39 & -6.89 & -8.84 & -12.39 & -10.53 & -0.43 & -2.95 & -8.26 & -4.20 & 4.87 & 13.73 \\
\hline 2004-05 & 31.85 & 23.23 & 19.06 & 21.56 & 21.75 & 23.37 & 38.57 & 58.14 & 67.14 & 54.76 & 43.61 & 48.47 \\
\hline 2005-06 & 56.95 & 45.68 & 45.00 & 45.68 & 41.32 & 38.64 & 45.60 & 61.82 & 52.13 & 95.69 & 74.77 & 82.00 \\
\hline 2006-07 & 76.76 & 62.94 & 71.77 & 12.42 & 162.84 & 178.76 & 153.31 & 113.06 & 103.86 & 111.72 & 159.42 & 249.25 \\
\hline 2007-08 & 251.12 & 336.66 & 353.77 & 79.00 & 454.97 & 359.32 & 192.72 & 76.65 & 90.71 & 29.09 & 226.87 & 233.79 \\
\hline 2008-09 & 326.38 & 195.68 & 133.14 & -9.57 & -93.63 & -175.99 & -176.71 & -172.19 & -175.88 & -168.39 & -141.48 & -62.80 \\
\hline 2009-10 & -93.50 & -148.85 & -178.00 & -216.12 & -195.38 & -203.96 & -221.45 & -223.38 & -230.02 & -176.34 & -138.59 & -113.02 \\
\hline 2010-11 & -122.98 & -159.48 & -131.45 & -114.71 & -132.11 & -110.62 & -94.66 & -97.27 & -91.79 & -104.35 & -138.53 & -64.27 \\
\hline 2011-12 & -65.90 & -85.21 & -67.30 & -66.00 & -69.49 & -55.61 & -59.52 & -49.29 & -36.57 & 34.80 & 11.62 & 38.45 \\
\hline 2012-13 & 40.85 & 66.91 & 74.20 & 122.92 & 133.10 & 156.39 & 130.42 & 152.43 & 121.47 & 80.16 & 75.82 & 90.15 \\
\hline 2013-14 & 97.20 & 101.40 & 108.00 & 123.00 & 234.65 & 268.91 & 258.21 & 223.3 & 236.59 & 249.34 & 278.02 & 371.86 \\
\hline 2014-15 & 353.70 & 219.68 & 202.94 & 129.00 & 160.40 & 160.74 & 181.21 & 152.14 & 101.46 & 71.98 & 49.42 & 58.89 \\
\hline $2015-1$ & 234.04 & 25 & 174. & 117. & 129. & 181. & 237 & 182.84 & 334 & 400 & 497 & 559.17 \\
\hline 2016-17 & 518.43 & 527.37 & 519.98 & 381.98 & 181. & 103.76 & -98.00 & -58.70 & 256.23 & 194 & 97.96 & 71.71 \\
\hline 2017-18 & 96.12 & -23.24 & -9.14 & -92.77 & -68.26 & -154.76 & -193.88 & -266.6 & -253.02 & -168.55 & -231.59 & -242.06 \\
\hline $2017-18$ & - & - & 58.76 & 47.86 & 63.61 & 44.69 & 36.20 & 13.41 & 30.83 & 43.04 & 45.56 & 36.68 \\
\hline
\end{tabular}

Source: Appendix- $B$

Momentum, as stated above, compares the most recent close to the close of a specific number of period's ago. Simply, it measures the movement of the market index or price. If the momentum crosses under the 0 (zero) line, it could be constructed as a bearish sign, above the 0 (zero) line, as bullish. The straight line shows the mark of the zero line. Figure 1 and Table 3 show that the NEPSE was at bearish trends from the F/Y 2001-02 to F/Y 20004-05 and again repeated the bearish trend from the F/Y 2007-08 till F/Y 2011-12. The bearish trend was seen again after the month of August-September 2017 and the trend continued. As the momentum line was seen above 0 (zero) line for the remaining fiscal years, the market can be stated in a bullish trend for these fiscal years. 


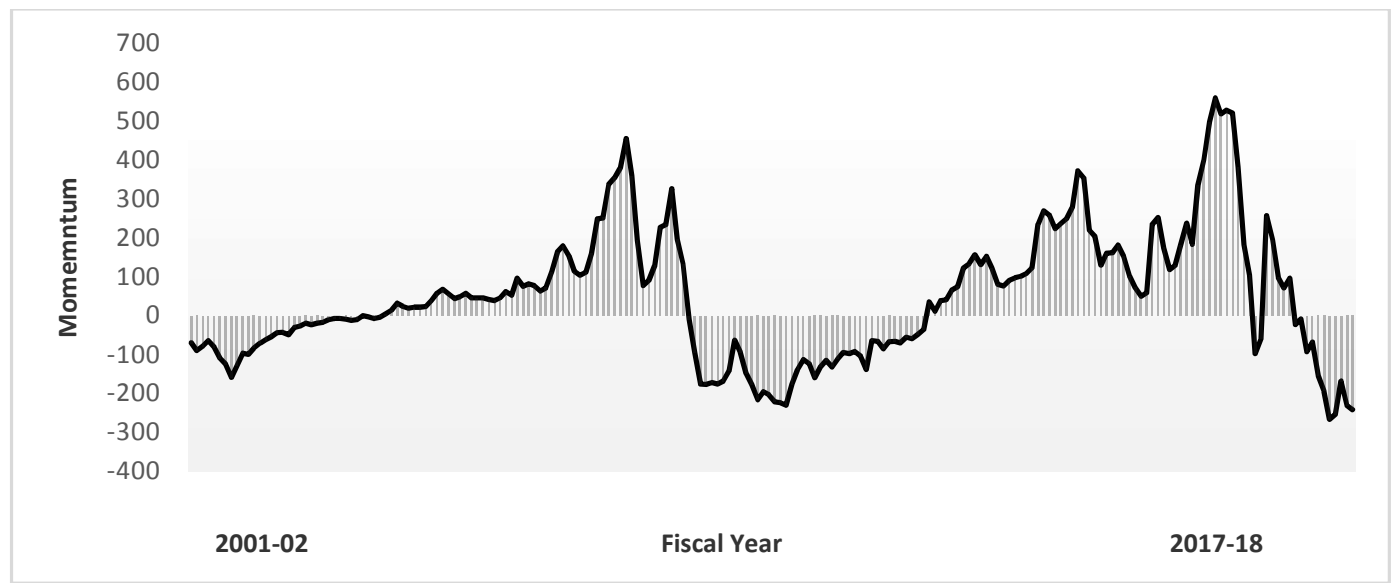

Figure1. Momentum of NEPSE Index

\section{CONCLUSION AND IMPLICATIONS}

There are numerous equipment and strategies utilized in the technical analysis. An investor can choose a suitable approach or a tool for studying and decoding the trend of the market. Investors are usually keen to recognize the overbought or oversold scenario of the market. It allows them to realize the true values of securities traded in the market. If the securities are overbought, it normally displays that they're being traded above their real price. The outcomes are that the trend will continue for short-run and could observe the appropriate course within the coming days. At the meantime, if the indicators from the market show oversold, it displays that the market goes in a downtrend or may additionally decline because of retracement or for a few consolidations.

There's a moderate version in an interpretation and use of the two stochastic techniques namely; \%K and $\% \mathrm{D}$ signs. The $\% \mathrm{~K}$ uses and interprets a short-term moving average whereas $\% \mathrm{D}$ interpret a longerterm moving average. For an investor who prefers to apply stochastic oscillator tools, they ought to use the results of both the $\% \mathrm{~K}$ as well as $\% \mathrm{D}$ line values. The overall rule is to have the sluggish $\% \mathrm{~K}$ line cross underneath the $\% \mathrm{D}$ line for a promote sign, or for the sluggish $\% \mathrm{~K}$ circulate above the $\% \mathrm{D}$ for a buy sign. That is similar to the bullish or bearish signal of a faster moving average crossing over (under) the slower moving average. As an example, the consequences from the NEPSE index for the duration of the F/Y 2017-18, in the month of September-October, the price of $\% \mathrm{~K}$ is visible above $\% \mathrm{D}$, which reflects to sell during this month and at the equal time, the state of affairs is vice-versa for the duration of the month of May-June.

In context to momentum additionally, it displays the overbought or oversold position of the market. The transaction sign or trade signal for the investor can be without difficulty detected the use of the 'zero line' of the momentum. Whilst the market index from the momentum calculation is going up the 'zero line', the market tends to emerge as bullish and vice versa. Consequently, it is straightforward to interpret the stock market trend using a simple mathematical calculation and graphical presentation. 


\section{REFERENCES}

Jegadeesh, N., \& Titman, S. (1993). Returns to buying winners and selling losers: Implications for stock market efficiency. Journal of Finance, 48 (1), 65-91.

Jegadeesh, N., \& Titman. S. (2001). Profitability of momentum strategies: An evaluation of alternative explanations. Journal of Finance, 56(2), 699-720.

Lane, G. C. (1984). Lane's stochastics. Technical Analysis of Stocks \& Commodities, 2, 87-90.

Lane, G.C. (1985). Lane's stochastics: The ultimate oscillator. CMT Association Journal, 21, 37-42.

Lee, C.M.C., \& Swaminathan, B. (2000). Price momentum and trading volume. The Journal of Finance, 55 (5), 2017-2069.

Nison, S. (1991). Japanese candlestick charting technique. New York: New York Institute of Finance.

Murphy, J. J. (1999). Technical analysis of the financial markets: A comprehensive guide to trading methods and applications. New York: Penguin.

Tonks, I., \& Hon, M.T. (2003). Momentum in the UK stock market. Journal of Multinational Financial Management. 13(1), 43-70.

Turner, T. (2007). A beginner's guide to day trading online ( $2^{\text {nd }}$ ed.). New York: Adams Media, Simon and Schuster.

Appendix: A

Calculation of $\% \mathrm{~K}$

\begin{tabular}{lccccc}
\hline F-Y 2017-18 & Open & High & Low & Close & \%K Line \\
\hline July-Aug & 1583.57 & 1667.94 & 1583.57 & 1632.66 & 58.18 \\
Aug-Sept & 1629.75 & 1629.75 & 1493.20 & 1530.31 & 27.18 \\
Sept-Oct & 1547.94 & 1564.90 & 1501.89 & 1559.18 & 90.92 \\
Oct-Nov & 1568.35 & 1571.92 & 1460.73 & 1489.06 & 25.48 \\
Nov-Dec & 1475.72 & 1537.67 & 1469.16 & 1520.15 & 74.43 \\
Dec-2018 Jan & 1509.14 & 1509.14 & 1390.58 & 1431.10 & 34.18 \\
Jan-Feb & 1413.71 & 1413.71 & 1380.29 & 1380.29 & 0.00 \\
Feb-Mar & 1388.94 & 1424.95 & 1277.01 & 1285.96 & 6.05 \\
Mar-Apr & 1288.36 & 1294.65 & 1168.55 & 1277.55 & 86.44 \\
Apr-May & 1280.15 & 1438.49 & 1280.15 & 1338.17 & 36.64 \\
May-Jun & 1333.85 & 1339.65 & 1231.64 & 1247.30 & 14.50 \\
Jun-July & 1233.23 & 1235.15 & 1179.71 & 1212.36 & 58.89 \\
\hline
\end{tabular}

Note. The calculation for the earlier fiscal year has also been done as above technique. 
Appendix: B

Calculation of Momentum

\begin{tabular}{|c|c|c|c|}
\hline Month & Close & SMA & Momentum \\
\hline Nov-Dec & 168.75 & - & - \\
\hline Dec-Jan 2000 & 181.67 & - & - \\
\hline Jan-Feb & 188.38 & - & - \\
\hline Feb-Mar & 216.92 & - & - \\
\hline Mar-Apr & 245.41 & - & - \\
\hline Apr-May & 269.88 & - & - \\
\hline May-Jun & 331.76 & - & - \\
\hline Jun-July & 360.70 & - & - \\
\hline July-Aug & 364.24 & - & - \\
\hline Aug-Sept & 421.18 & - & - \\
\hline Sept-Oct & 433.92 & - & - \\
\hline Oct-Nov & 519.33 & - & - \\
\hline Nov-Dec & 488.05 & - & - \\
\hline Dec-2001 Jan & 464.76 & - & - \\
\hline Jan-Feb & 455.34 & - & - \\
\hline Feb-Mar & 395.85 & - & - \\
\hline Mar-Apr & 369.05 & - & - \\
\hline Apr-May & 355.60 & - & - \\
\hline May-Jun & 333.18 & - & - \\
\hline Jun-July & 348.30 & - & - \\
\hline July-Aug & 281.04 & 351.23 & -70.19 \\
\hline Aug-Sept & 265.22 & 355.41 & -90.19 \\
\hline Sept-Oct & 281.21 & 360.05 & -78.84 \\
\hline Oct-Nov & 300.15 & 364.21 & -64.06 \\
\hline Nov-Dec & 284.48 & 366.16 & -81.68 \\
\hline Dec-2002 Jan & 255.92 & 365.46 & -109.54 \\
\hline Jan-Feb & 236.01 & 360.68 & -124.67 \\
\hline Feb-Mar & 193.83 & 352.33 & -158.50 \\
\hline Mar-Apr & 216.21 & 344.93 & -128.72 \\
\hline Apr-May & 239.09 & 335.83 & -96.74 \\
\hline May-Jun & 226.04 & 325.43 & -99.39 \\
\hline Jun-July & 227.54 & 310.84 & -83.30 \\
\hline
\end{tabular}

Note. The calculation for the remaining fiscal year has also been done as above technique. 